\title{
TERAPI AKTIVITAS KELOMPOK TERHADAP KUALITAS HIDUP PENGARUH LANSIA
}

\author{
Juliandi ${ }^{1}$, Cecep Triwibowo ${ }^{2}$ \\ Poltekkes Kemenkes Medan \\ Email : juliandi1975@gmail.com ${ }^{1}$
}

\begin{abstract}
Group therapy is a method of treatment that is carried out when a patient is met in a certain time frame with personnel who meet certain requirements. The quality of life is closely related to the environment where the elderly live. The elderly generally live with their families, but not a few elderly people live in nursing homes.

There is a significant difference in the quality of life of the elderly in the UPT Social Services for the elderly and children under five in Binjai area between before and after giving group activity therapy in the intervention group with a $p$ value of 0.008.There was no significant difference in the quality of life of the elderly in the UPT Social Services for the elderly and children under five in Binjai area between before and after giving group activity therapy to the control group with a $p$ value of 0.317.There was a significant difference in the quality of life of the elderly in the UPT Social Services for the elderly and children under five in Binjai area between the intervention group and the control group with a $p$ value of 0.043 .
\end{abstract}

Keywords: Group Therapy, Quality of Life, Elderly

\begin{abstract}
Abstrak
Terapi kelompok adalah metode pengobatan yang dilakukan ketika pasien ditemui dalam rancangan waktu tertentu dengan tenaga yang memenuhi persyaratan tertentu.Kualitas hidup berkaitan erat dengan lingkungan tempat tinggal lansia. Lansia pada umumnya tinggal bersama dengan keluarga, namun tidak sedikit lansia yang tinggal di panti jompo. Terdapat perbedaan yang bermakna kualitas hidup lansia di UPT Pelayanan Sosial Lanjut Usia dan Anak Balita Wilayah Binjai antara sebelum dan sesudah pemberian terapi aktivitas kelompok pada kelompok intervensi dengan nilai $p$ sebesar 0,008 . Tidak terdapat perbedaan yang bermakna kualitas hidup lansia di UPT Pelayanan Sosial Lanjut Usia dan Anak Balita Wilayah Binjai antara sebelum dan sesudah pemberian terapi aktivitas kelompok pada kelompok kontrol dengan nilai $p$ sebesar 0,317. Terdapat perbedaan yang bermakna kualitas hidup lansia di UPT Pelayanan Sosial Lanjut Usia dan Anak Balita Wilayah Binjai antara kelompok intervensi dibandingkan dengan kelompok kontrol dengan nilai $p$ sebesar 0,043 .
\end{abstract}

Kata Kunci : Terapi Kelompok, Kualitas Hidup, Lansia 


\section{PENDAHULUAN}

Lanjut usia (lansia) bukan suatu penyakit, namun merupakan tahap lanjut dari suatu proses kehidupan yang ditandai dengan penurunan kemampuan tubuh untuk beradaptasi dengan stress lingkungan. Seseorang dikatakan lanjut usia apabila usianya lebih dari 65 tahun ke atas (Efendi dan Mahfudin 2009).

Klasifikasi lansia terbagi menjadi lima klasifikasi yang terdiri dari: Pralansia (presinilas) yaitu seseorang yang berusia antara 45-59 tahun, lansia yaitu seseorang yang berusia 60 tahun atau lebih, lansia resiko tinggi yaitu seseorang yang berusia 70 tahun atau lebih dengan masalah kesehatan, lansia potensial yaitu lansia yang masih mampu bekerja yang dapat menghasilkan barang atau jasa, lansia tidak potensial yaitu lansia yang hidupnya bergantung pada bantuan orang lain (Maryan dkk 2008).

Populasi lansia mengalami peningkatan daritahun ketahun.World Health Organization (WHO) mencatat bahwa terdapat 600 juta jiwa lansia pada tahun 2012 di seluruh dunia. Menurut data Biro Pusat Statistik (BPS), tercatat jumlah lansia Indonesia mencapai jumlah 28 juta jiwa pada tahun 2012 dari yang hanya 19 juta jiwa pada tahun 2006. Pada tahun 2025, Indonesia akan mengalami peningkatan lansia sebesar $41,4 \%$, yang merupakan peningkatan tertinggi di dunia (Kemenkes, 2012).

Kualitas hidup berkaitan erat dengan lingkungan tempat tinggal lansia. Lansia pada umumnya tinggal bersama dengan keluarga, namun tidak sedikit lansia yang tinggal di panti jompo (putri $\mathrm{dkk}$, 2015). Beberapa penelitian membandingkan kualitas hidup lansia yang tinggal di panti jompo dan keluarga. Putri dkk (2015) menyatakan bahwa lansia yang tinggal di lansia memiliki kualitas hidup yang lebih rendah pada semua domain yaitu fisik, psikologis, social, dan lingkungan dibandingkan dengan lansia yang tinggal bersama keluarga. Sementara Rohmah (2012) mengkaji kualitas hidup pada suatu panti jompo diperoleh mayoritas lansia memiliki kualitas hidup yang sedang dengan penjabaran pada setiap domain diperoleh kategori kurang baik pada domain fisik dan social, kategori cukup dan baik secara berurutan pada domain lingkungan dan psikologis. Berdasarkan hal tersebut, perlu adanya terobosan seperti terapi-terapi yang dapat meningkatkan kualitas hidup lansia yang tinggal di panti jompo.

Terapi modalitas merupakan proses pemulihan fungsi fisik, mental-emosional, dan sosial ke arah keutuhan pribadi yang dilakukan secara holistik.
Pasien sebagai manusia yang meliputi biologis, psikologis, sosial dan spritual tentu saja memiliki masalah yang multikompleks, dengan demikian penanganannya pun tentu harus multidisipliner. Pemberian terapi baik psikofarmakologi maupun keperawatan yang tepat dan akurat saja tidak cukup, tetetapi harus disusul dengan terapi modalitas yang dipilih secara teratur dan kontinu sampai berfungsinya kembali perilaku normatif yang stabil atau perilakunya adaptif. Keberhasilan terapi psikis ini sangat tergantung pada adanya komunikasi antara perawat dan pasien (Chaudhury, 2010).

Terapi modalitas yang diberikan berupa psikoterapi individu dan terapi kelompok. Terapi kelompok adalah metode pengobatan yang dilakukan ketika pasien ditemui dalam rancangan waktu tertentu dengan tenaga yang memenuhi persyaratan tertentu. Fokus terapi kelompok adalah membuat pasien menjadi sadar diri, peningkatan hubungan interpersonal ini, membuat perubahan, atau ketiganya. Terapi aktivitas kelompok dibagi sesuai dengan kebutuhan yaitu, stimulasi persepsi, stimulasi sensoris, orientasi realita, dan sosialisasi (Keliat \& Akemat, 2005).

Terapi kelompok adalah metode pengobatan ketika lansia ditemui dalam rancangan waktu tertentu dengan tenaga yang memenuhi persyaratan tertentu.fokus terapi kelompok adalah membuat sadar diri (self-awereness), peningkatan hubungan interpersonal, membuat perubahan, atau ketiganya (Kelliat dan Akemat, 2005).

Terapi aktivitas kelompok stimulasi persepsi bertujuan untuk melatih pasien memersepsikan stimulus yang disediakan atau stimulus yang pernah dialami. Kemampuan persepsi pasien dievaluasi dan ditingkatkan pada setiap sesi. Proses ini mengharapkan respons yang muncul dari pasien terhadap berbagai stimulus dalam kehidupan menjadi adaptif (Keliat \& Akemat, 2005). Berbagai penelitian membuktikan bahwa TAK dapat meningkatkan kemandirian pada pasien jiwa (Handayani et al, 2013).

Selain itu TAK juga terbukti dapat meningkatkan ketrampilan social dasar pada pasien skizofrenia (Hartono, 2012). Namun penelitian terkait efektivitas TAK terhadap kualitas hidup pada lansia khususnya yang tinggal di panti jompo belum pernah dilakukan. Oleh karena itu, peneliti tertarik untuk memberikan intervensi berupa TAK terhadap kualitas hidup pada lansia. 


\section{Kerangka Konsep Penelitian}

Adapun kerangka konsep penelitian adalah sebagai berikut :

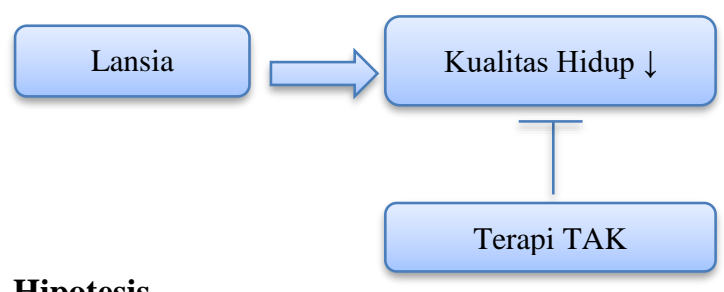

\section{Hipotesis}

Ada beda tingkat kualitas hidup sebelum dan sesudah terapi aktivitas kelompok pada lansia di UPT Pelayanan Sosial Lanjut Usia Binjai.

Ada beda tingkat kualitas hidup pada kelompok intervensi dibandingkan kelompok kontrol pada lansia di UPT Pelayanan Sosial Lanjut Usia Binjai.

\section{Metode Penelitian}

Jenis penelitian ini adalah quasi experiment (eksperimen semu), dengan rancangan pre-post-test control-group design yaitu dengan membandingkan nilai pretest dengan posttest pada kelompok intervensi dan kelompok kontrol. Pada penelitian ini, peneliti memberikan terapi aktivitas kelompok, sebelum dan sesudah terapi peneliti akan membagikan kuisioner terkait kualitas hidup untuk mengetahui tingkat kualitas hidup lansia baik pada kelompok intervensi maupun kontrol.

Populasi dalam penelitian ini adalah seluruh pasien di Panti Werdha Binjai. Besar sebanyak 180 orang, tetapi untuk dijadikan sampel penelitian sebanyak 36 orang.

\section{Tahapan Penelitian}

Proses tahapan penelitian ini yaitu:

1. Mengurus surat perizinan di Dinas Sosial Provinsi Sumatera Utara

2. Survei awal

3. Pendataan

4. Sosialisasi

5. Mengajukan informed consent penelitian kepada responden

6. Pelaksanaan penelitian

a. Pengambilan data kualitas hidup sebelum intervensi dengan cara memberikan kuisioner.

b. Intervensi yaitu pemberian terapi aktivitas kelompok

Parameter :TAK stimulasi Persepsi.

Sesi 1 : mengidentifikasi hal positif diri.

Sesi 2 : melatih positif diri dan orang lain

Sesi 3 : Menentukan tujuan hidup
Alat Ukur :Prosedur TAK stimulasi persepsi Metode diskusi dan permainan

1. Orientasi Salam, memperkenalkan diri

2. Evaluasi Validasi menanyakan perasaan lansia saat ini

3. Kontrak Menjelaskan tujuan kegiatan yaitu mengetahui positif diri

4. Kerja Terapis memperkenalkan diri, membagikan spidol dan kertas dan meminta lansia bercerita tentang pengalaman yang menyenangkan maupun tidak menyenangkan

5. Terminasi Menanyakan perasaan lansia setelah mengikuti kegiatan saat ini

Waktu optimal untuk satu sesi 15-25 menit. Banyaknya sesi tergantung pada tujuan kelompok, dapat satu kali / dua kali per minggu; atau dapat direncanakan sesui dengan kebutuhan

c. Setelah intervensi berakhir dilakukan pengambilan data pengukuran kualitas hidup dengan cara membagikan kuisioner.

\section{A. Analisis Data}

\section{Analisa Univariat}

Univariat digunakan untuk melakukan analisa terhadap distribusi frekuensi hasil pengukuran sebuah data dengan cara mendeskriptifkan setiap data tersebut. Dalam penelitian ini hasil pengukuran skala kecemasan ditampilkan dalam bentuk kategori dan kemudian difrekuensikan.

2. Analisa Bivariat

Analisis bivariat bertujuan membuktikan kebenaran hipotesis yang telah dirumuskan. Analisis hasil untuk penelitian ini menggunakan program SPSS versi 19. Wilcoxon digunakan untuk mengetahui adanya efek karena perlakukan pada satu kelompok dengan pre dan post tes. Mann whitney-test digunakan untuk mengetahui perbedaan kualitas hidup pada kelompok kontrol dan intervensi. Perbedaan dinyatakan signifikan apabila $\mathrm{P}<0,05$.

\section{Hasil Penelitian}

Penelitian ini bertujuan untuk mengetahui pengaruh terapi aktivitas kelompok terhadap kualitas hidup pada lansia di UPT pelayanan sosial lanjut usia dan anak balita wilayah Binjai, adapun hasil penelitian sebagai berikut:

Tabel. 4.1. Distribusi Frekensi Responden berdasarkan suku di UPT pelayanan sosial lanjut usia dan anak balita wilayah Binjai

\begin{tabular}{clcc}
\hline No. & \multicolumn{1}{c}{ Suku } & Frekuensi & $\begin{array}{c}\text { Presentase } \\
(\%)\end{array}$ \\
\hline 1 & Jawa & 19 & $\mathbf{5 2 , 7 8 \%}$ \\
2 & Batak & 8 & $22,22 \%$ \\
3 & Melayu & 6 & $16,66 \%$ \\
4 & Minang & 3 & $8,33 \%$ \\
& Kabau & & \\
\hline & Total & $\mathbf{3 6}$ & $100 \%$ \\
\hline
\end{tabular}

Sumber : Hasil penelitian 2018 
Berdasarkan tabel 4.1. mayoritas lansia di UPT pelayanan sosial lanjut usia dan anak balita wilayah Binjai yang menjadi responden dalam penelitian ini yaitu berasal dari suku jawa dengan presentase $52,78 \%$ dan yang terendah yaitu dari suku minangkabau dengan presentase $8,33 \%$.

Tabel 4.2. Distribusi Frekensi Responden

berdasarkan jenis kelamin di UPT pelayanan

sosial lanjut usia dan anak balita wilayah Binjai

\begin{tabular}{llcc} 
No. & $\begin{array}{c}\text { Jenis } \\
\text { Kelamin }\end{array}$ & Frekuensi & $\begin{array}{c}\text { Presentase } \\
(\%)\end{array}$ \\
\hline 1 & Perempuan & 19 & $\mathbf{5 2 . 7 8} \%$ \\
2 & Laki-Laki & 17 & $47,22 \%$ \\
\hline 3 & Total & 36 & $100 \%$ \\
\hline
\end{tabular}

Sumber : Hasil penelitian 2018

Berdasarkan tabel 4.2 mayoritas lansia di UPT pelayanan sosial lanjut usia dan anak balita wilayah Binjai yang menjadi responden dalam penelitian ini yaitu berjenis kelamin perempuan sebanyak 52,78\%.

Tabel 4.3. Distribusi Frekuensi

Responden berdasarkan Agama di UPT pelayanan sosial lanjut usia dan anak balita wilayah Binjai

No. Agama Frekuensi Peresentase (\%)

\begin{tabular}{llcc}
\hline 1 & Islam & 29 & $\mathbf{8 0 , 5 6 \%}$ \\
2 & Kristen & 7 & $19,44 \%$ \\
\hline 3 & Total & 36 & $100 \%$ \\
\hline
\end{tabular}

Sumber : Hasil penelitian 2018

Berdasarkan tabel 4.3. mayoritas lansia di UPT pelayanan sosial lanjut usia dan anak balita wilayah Binjai yang menjadi responden dalam penelitian ini yaitu beragama Islam sebanyak 80,56\%.

Tabel. 4.4. Distribusi Frekuensi Responden berdasarkan Umur UPT pelayanan sosial lanjut usia dan anak balita wilayah Binjai

\begin{tabular}{llcc}
\hline No. & Umur & Frekuensi & $\%$ \\
\hline 1 & $50-55$ & 5 & $13,89 \%$ \\
2 & $55-60$ & 7 & $19,44 \%$ \\
3 & $60-65$ & 9 & $25 \%$ \\
4 & $>65$ & 15 & $\mathbf{4 1 , 6 7 \%}$ \\
\hline & Total & $\mathbf{3 6}$ & $100 \%$ \\
\hline
\end{tabular}

Sumber : Hasil penelitian 2018

Berdasarkan tabel 4.4. mayoritas lansia di UPT pelayanan sosial lanjut usia dan anak balita wilayah Binjai yang menjadi responden dalam penelitian ini yaitu berumur lebih dari 65 tahun sebanyak 41,67\% dan yang terendah yaitu berumur antara 50-55 tahun sebanyak 13,89\%.

Sebelum dilakukan terapi aktivitas, dilakukan pengukuran kualitas hidup, kemudian dilakukan terapi aktivitas kelompok sebanyak 2 kali/minggu selama 4 minggu. Pada akhir pertemuan dilakukan pengukuran kualitas hidup kembali untuk mengetahui efektivitas terapi. Pada kelompok kontrol juga dilakukan dua kali pengukuran kualias hidup lansia pada awal dan akhir penelitian. Adapun kategori kualitas hidup lansia pada awal dan akhir penelitian baik kelompok intervensi maupun kelompok kontrol tersaji dalam grafik 4.1.
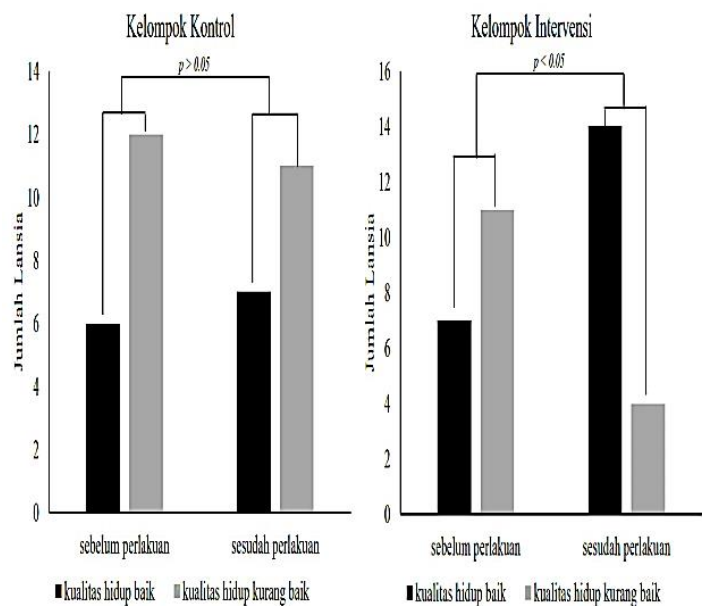

Sumber : Hasil penelitian 2018

Grafik 4.5. Kualitas hidup lansia pada kelompok kontrol dan kelompok intervensi di UPT pelayanan sosial lanjut usia dan anak balita wilayah Binjai

Berdasarkan grafik tersebut, pada kelompok kontrol, pemeriksaan awal dan pemeriksaan akhir mayoritas lansia memiliki kualitas hidup kurang baik yaitu berturut sebanyak 12 orang dan 11 orang. Pada kelompok intervensi, sebelum pemberian terapi aktivitas kelompok mayoritas lansia memiliki kualitas hidup kurang baik sebanyak 11 orang, dan setelah pemberian terapi aktivitas kelompok mayoritas lansia memiliki kualitas hidup baik sebanyak 14 orang. Hasil uji Wilcoxon pada kelompok kontrol diketahui nilai $p$ sebesar 0,317 $(p>0,05)$ yang berarti tidak ada perbedaan antara kualitas hidup pada awal pemeriksaan dan akhir pemeriksaan. Sementara itu, pada kelompok intervensi diperoleh nilai $p$ sebesar $0,008(p<0,05)$ yang berarti terdapat perbedaan yang signifikan kualitas hidup lansia sesudah pemberian terapi aktivitas kelompok dibandingkan sebelum intervensi.

Selanjutnya data kualitas hidup sesudah perlakuan digunakan untuk uji mann whitney untuk mengetahui perbedaan kualitas hidup antara kelompok kontrol dan kelompok intervensi. Data tersebut tersaji dalam tabel 4.6. 
Tabel 4.6. Perbedaan kualitas hidup lansia pada kelompok kontrol dan kelompok intervensi di UPT Pelayanan Sosial Lanjut Usia dan Anak Balita Wilayah Binjai $(\mathrm{n}=18)$

\begin{tabular}{lccccc}
\hline $\begin{array}{l}\text { Kualitas } \\
\text { hidup }\end{array}$ & Kelompok kontrol & \multicolumn{2}{c}{$\begin{array}{c}\text { Kelompok } \\
\text { intervensi }\end{array}$} & $\begin{array}{c}\text { Nila } \\
\text { i } p\end{array}$ \\
\hline $\begin{array}{l}\text { Kualitas } \\
\text { hidup baik }\end{array}$ & $\mathrm{N}$ & $\%$ & $\mathrm{~N}$ & $\%$ & \\
$\begin{array}{l}\text { Kualitas } \\
\text { hidup kurang }\end{array}$ & 11 & $\begin{array}{c}38,8 \\
9\end{array}$ & 14 & $\begin{array}{c}77, \\
78\end{array}$ & 0,04 \\
baik & 18 & 4 & $\begin{array}{c}22, \\
22\end{array}$ & 3 \\
\hline Total & 100 & 18 & $\begin{array}{c}10 \\
0\end{array}$ & \\
\hline
\end{tabular}

Sumber : Hasil penelitian 2018

Berdasarkan tabel 4.6. diperoleh nilai $p$ sebesar 0.043 $(p<0,05)$, yang berarti terdapat perbedaan yang signifikan kualitas hidup kelompok intervensi dibandingkan dengan kelompok kontrol pada lansia di UPT Pelayanan Sosial Lanjut Usia dan Anak Balita Wilayah Binjai.

\section{Pembahasan}

Berdasarkan hasil penelitian, pada pemeriksaan awal baik kelompok kontrol maupun kelompok intervensi, mayoritas lansia di UPT Pelayanan Sosial Lanjut Usia dan Anak Balita Wilayah Binjai memiliki kualitas hidup yang kurang baik. Hasil penelitian ini sejalan dengan penelitian yang dilakukan oleh Sari dan Susanti (2017), bahwa lansia yang tinggal di panti sosial memiliki kualitas hidup yang kurang baik. Hasil serupa juga disampaikan oleh Putri et al. bahwa lansia yang hidup di panti social memiliki kualitas hidup yang kurang baik dibandingkan dengan lansia yang tinggal dengan keluarga. Sebaliknya, Putra et al. (2014) dan Yuliati et al (2014) memaparkan bahwa lansia yang tinggal di panti social memiliki kualitas hidup yang baik, bahkan ketika dibandingkan dengan lansia yang tinggal dikeluarga, kualitas hidup lansia yang tinggal di panti asuhan lebih baik.

Kualitas hidup adalah sejauh mana seseorang dapat merasakan dan menikmati terjadinya segala peristiwa penting dalam kehidupannya sehingga kehidupannya menjadi sejahtera (Rapley, 2003). Jika seseorang dapat mencapai kualitas hidup yang tinggi, maka kehidupan individu tersebut mengarah pada keadaan sejahtera (wellbeing), sebaliknya jika seseorang mencapai kualitas hidup yang rendah, maka kehidupan individu tersebut mengarah pada keadaan tidak sejahtera (ill-being) (Brown, 2004).

Menurut Nur Rohmah et al (2012), terdapat 4 faktor yang mempengaruhi kualitas hidup yaitu faktor fisik, faktor psikologis, faktor sosial, dan faktor lingkungan. Selanjutnya, aspek kesehatan fisik dan aspek psikologi menjadi faktor utama yang menyebabkan rendahnya kualitas hidup lansia. Kesehatan fisik dapat mempengaruhi kemampuan individu untuk melakukan aktivitas. Berdasarkan Kurniawan dan Lembar (2004), pada proses menua terjadi kemunduran fisik akibat penurunan fungsi organ disertai dengan penyakit-penyakit kronik.

Aspek psikologis yaitu terkait dengan keadaan mental individu. Keadaan mental mengarah pada mampu atau tidaknya individu menyesuaikan diri terhadap berbagai tuntutan perkembangan sesuai dengan kemampuannya, baik tuntutan dari dalam diri maupun dari luar dirinya. Aspek psikologis juga terkait dengan aspek fisik, dimana individu dapat melakukan suatu aktivitas dengan baik bila individu tersebut sehat secara mental. Aspek psikologi disebabkan karena adanya perasaan takut menghadapi kematian, perasaan sedih dan putus asa, merasa kesepian karena jauh dari anak, sanak dan kerabat dan ingin tinggal bersama keluarga.

Keluarga berperan penting dalam meningkatkan kualitas hidup lansia. Lansia yang memiliki kedekatan dengan keluarga dimana keluarga merupakan sumber dukungan emosional. Dukungan sosial yang diterima akan berpengaruh terhadap kualitas hidup lansia (Setyoadi et al., 2010). Dukungan pada keluarga dan masyarakat yang kurang akan membuat lansia mengalami perubahan negative terhadap kehidupannya, dan sebaliknya bila dukungan keluarga dan masyarakat cukup baik maka akan membuat lansia mengalami perubahan yang positive dalam kehidupannya, kedua hal ini akan mempengaruhi kualitas hidup pada lansia (Potter\&Perry, 2005).

Berdasarkan hasil penelitian, terapi aktivitas kelompok dapat meningkatkan kualitas hidup lansia di UPT pelayanan sosial lanjut usia dan anak balita wilayah Binjai, sebaliknya pada kelompok kontrol kualitas hidup lansia tidak mengalami perbedaan yang bermakna antara pemeriksaan awal dan akhir. Hal ini membuktikan bahwa peningkatan kualitas hidup lansia hanya dipengaruhi oleh terapi aktivitas kelompok.

Dalam berbagai penelitian terapi aktivitas kelompok berhasil memperbaiki, kecemasan, interaksi sosial sampai kualitas tidur lansia (khamida dan Meilisa, 2016; Aris, 2016). Menurunnya kecemasan, meningkatnya interaksi sosial, dan kualitas tidur yang baik merupakan indikasi yang berpengaruh terhadap kualitas hidup lansia yang baik. 
Terapi aktivitas kelompok (TAK) merupakan salah satu terapi modalitas yang dilakukan perawat pada sekelompok pasien yang mempunyai masalah keperawatan yang sama. Kelompok memiliki kekuatan yang besar untuk dapat saling memotivasi dan mempengaruhi satu sama lainnya. Kelompok adalah membantu anggotanya berhubungan dengan orang lain serta mengubah perilaku yang destruktif dan maladaptive kekuatan kelompok ada pada kontribusi setiap anggotanya. Kelompok berfungsi sebagai tempat berbagi pengalaman dan saling membantu satu sama lain, untuk menemukan cara menyelesaikan masalah. Kelompok merupakan laboratorium tempat mencoba dan menemukan hubungan interpersonal yang baik, serta mengembangkan perilaku yang adaptif. Anggota kelompok merasa dimiliki, diakui, dan dihargai eksistensinya oleh anggota kelompok yang lain

\section{KESIMPULAN DAN SARAN}

\section{Kesimpulan}

Terdapat perbedaan yang bermakna kualitas hidup lansia di UPT Pelayanan Sosial Lanjut Usia dan Anak Balita Wilayah Binjai antara sebelum dan sesudah pemberian terapi aktivitas kelompok pada kelompok intervensi dengan nilai $p$ sebesar 0,008 .

Tidak terdapat perbedaan yang bermakna kualitas hidup lansia di UPT Pelayanan Sosial Lanjut Usia dan Anak Balita Wilayah Binjai antara sebelum dan sesudah pemberian terapi aktivitas kelompok pada kelompok kontrol dengan nilai $p$ sebesar 0,317.

Terdapat perbedaan yang bermakna kualitas hidup lansia di UPT Pelayanan Sosial Lanjut Usia dan Anak Balita Wilayah Binjai antara kelompok intervensi dibandingkan dengan kelompok kontrol dengan nilai $p$ sebesar 0,043 .

\section{Saran}

Dengan melihat hasil kesimpulan diatas, maka ada beberapa saran dari penulis yakni sebagai berikut:

Bagi Akademis

Sebagai bahan pustaka dalam menambah wawasan pengetahuan khususnya tentang pengaruh terapi aktivitas kelompok terhadap kualitas hidup pada lansia dan sebagai sambungan pemikiran perkembangan ilmu pengetahuan untuk penelitian selanjutnya terutama di bidang kesehatan.

Bagi Praktisi

Bagi Tempat Penelitian

Diharapkan hasil penelitian ini dapat sebagai bahan pertimbangan oleh para pelaksana program dalam meningkatkan upaya di bidang kesehatan.
Bagi Responden

Dari hasil penelitian ini bisa dijadikan upaya dalam meningkatkan kualitas hidup pada lansia dengan cara melakukan terapi aktivitas kelompok (TAK) sewaktuwaktu.

Bagi profesi Keperawatan

Diharapkan penelitian ini memberikan masukan bagi profesi keperawatan tentang pengaruh terapi aktivitas kelompok terhadap kualitas hidup pada lansia

\section{DAFTAR PUSTAKA}

Aris, A. 2016. Pengaruh Terapi Aktivitas Kelompok (Tak)-Stimulasi Sensori Terhadap Tingkat Depresi Pada Lansia Di Upt Pelayanan Sosial Lanjut Usia Pasuruan Berlokasi Di Babat Kabupaten Lamongan. Surya, 8(2); 612.

Bandiyah, S 2009, Lanjut Usia Dan Keperawatan Gerontik. Nuhamedika : Yogjakarta . hal 23-25.

Departemen Kesehatan RI., (2012). Manajemen Upaya Kesehatan Usia Lanjutdi Puskesmas. Jakarta

Efendi, F. Mahfudin 2009, Keperawatan Kesehatan Komunitas. Jakarta : Salemba Medika. Hal 32-35.

Keliat dan Akemat. (2005). Keperawatan Jiwa. Terapi Aktivitas Kelompok. Jakarta : EGC

Keliat, W.A.P., (2011). Manajemen Kasus Gangguan Jiwa: CMHN (Intermediate Course). Jakarta: EGC.

Khaje-Bishaki, Y., Payahoo, L., Pourghasem, B., Jafarabadi, M.A. 2014. Assessing the Quality of Life in Elderly People and Related Factors in Tabriz, Iran. Journal of Caring Sciences, 3(4):257-263.

Khamida dan Meilisa. 2016. Terapi Aktivitas Kelompok (TAK) Stimulasi Persepsi dalam Menurunkan Tingkat Kecemasan Pada Lansia. Jurnal Ilmiah Kesehatan, 9(2); 121128.

Kurniawan, F. dan Lembar, S. 2004. Gambaran Status Kesehatan Lansia: Studi Kasus di Wilayah Paroki.

Maryam,SR,dkk.2008. Mengenai Usia Lanjut dan Perawatanya. Jakarta; Salemba Medika.

Nur Rohmah, A.I., Purwaningsih., Khoridatul Bariyah. 2012. Kualitas Hidup Lanjut Usia. Jurnal Keperawatan. Vol. 8 No.1 Januari 2017

Putri, D.L.N.A., Akhmadi, Subekti, H. 2008. Gambaran Kualitas Hidup LansiaYang Tinggal di Panti Sosial Tresna Werdha 
Yogyakarta Unit Budi Luhur. JIK 3(2): 7477.

Putri, S.T., Fitriana, LA., Ningrum, A., Sulastri, A. 2015. Studi Komparatif : Kualitas Hidup Lansia Yang Tinggal Bersama Keluarga Dan Panti. Program Studi Keperawatan FPOK Universitas Pendidikan Indonesia.

Rohmah, A.I.N., Purwaningsih, Bariyah, K. 2012. Kualitas Hidup Lanjut Usia. Jurnal Keperawatan, 3(2): 120-132.

Setyoadi, Noerhamdani, Ermawati. (2010). Perbedaan Tingkat Kualitas hidup pada lansia wanita di komunitas dan panti. Di akses melalui http://ejournal.umm.ac.id/index.php/kepera watan/article/viewFile/621/641_umm_scie ntific_journal.pdf

Stuart, W. G., (2006). Buku Saku Keperawatan Jiwa Edisi 5. EGC; Jakarta.

Suliswati., (2005). Konsep Dasar Keperawatan Jiwa. EGC; Jakarta

Titus Irto, Rachman Watief A, Arsyad Rahman. 2005. Gambaran Perilaku Lansia Terhadap Kecemasan di Panti Sosial Tresna Wredha Theodoro Makasar ;Jurnal. FKM Unhas Makasar. Hal 1-9.

Videbeck, S. L., (2008). Buku Ajar Keperawatan Jiwa Jakarta: Buku kedokteran.EGC.

Yosep.I. (2007). Keperawatan Jiwa. Bandung : Refika Aditama.

Yuliati, A., Baroya, N., dan Ririanty, M. 2014. Perbedaan Kualitas Hidup Lansia yang Tinggal di Komunitasdengan di Pelayanan Sosial Lanjut Usia. E-jurnal pustaka kesehatan, 2(1): 87-94. 